\title{
THE $6^{\text {TH }}$ RARE DISEASE SOUTH EASTERN EUROPE (SEE) MEETING, SKOPJE, MACEDONIA (NOVEMBER 11 ${ }^{\mathrm{TH}}, 2017$ )
}

\author{
Zoran Gucev $^{1}$, Velibor Tasic ${ }^{1}$, Momir Polenakovic ${ }^{2}$ \\ ${ }^{1}$ University Children's Hospital Medical School, Skopje, Republic of Macedonia \\ ${ }^{2}$ Macedonian Academy of Science and Arts, Skopje, Republic of Macedonia
}

Corresponding author: Prof. Momir Polenakovic, MD, PhD, Macedonia Academy of Sciences and Arts, Bul. Krste Misirkov, No. 2, 1000 Skopje, Republic of Macedonia; E-mail momir@manu.edu.mk

\section{ABSTRACT}

The sixth SEE meeting on rare diseases (RDs) was held in MASA the November 10th, 2017. A block of lectures on rare renal diseases started the meeting: nephrotic syndrome, Alport syndrome, atypical HUS, hypophosphatemic rickets, CAKUT were presented in all complexities. Their molecular and genetic mechanisms were discussed. The discovery of a dozen of newly genes in CAKUT, congenital overgrowth, spodilocostal dysplasia, precocious puberty has been done with collaboration of Macedonian and foreign researchers. NGS and other molecular methods in diagnosis of RDs have been presented by several presenters. The mitochondrial diseases, the novelties and importance of early discovery were comprehensively presented and discussed. The genetics and treatment of persistent neonatal hypoglcaemia were of special interest. Dysmorphic syndromes (Klippel Feil) were also presented. A session of oral electronic posters was reach and inspiring. Several lectures dealt with mucopolisaccaridoses, glycogen storage diseases and the possibilities for their diagnosis and treatment. Enzyme replacement treatement (ERT), its availability, effects (or the lack of it on the brain), intratecal ERT administration and further prospects of eventual gene treatment were comprehensively exposed and discussed. The main purposes of this traditional meeting are hopefully fulfilled: increased number of patients with RDs treated and cutting edge presentations got.

Keywords: Rare renal disease, NGS, mitochondrial diseases, new genes

\section{INTRODUCTION}

The Sixth Conference on Rare Disease in South Eastern Europe was held on November 11th in the Jubilee Year, fifty years from the foundation of the Macedonian Academy of Sciences and Arts. For this whole period the Academy has strongly supported scientific activities in the country, but also in the region and internationally. This year scientists and clinicians from Macedonia, Serbia, Croatia, Bosnia and Herzegovina, Kosovo, Austria and Germany have presented their achievements in the modern diagnostics and treatment of patients with rare diseases. 


\section{Presentations from Macedonia}

Momir Polenakovic from MASA, Skopje, Macedonia gave a talk on Rare Diseases (RD) in nephrology. He discussed the various definitions of RDs and their utilization in nephrology. Nephrotic syndrome, chronic glomerulonephritis, Alport syndrome were comprehensively discussed.

Vesna Aleksovska and Anja Bosilkova-Antovska, from Skopje, Macedonia, head patient organizations for RDs. They exposed the challenges and solutions for the national plan for RD in Macedonia. They discussed the difficulties of the following: access to diagnosis, treatment and social services; quality of health protection; high prices of treatment; consequences, marginalization and isolation of people with rare diseases. There are no practical regulations and the public, institutional and professional awareness is low.

This is why we need a national plan for rare diseases, with goals, measures and actions to improve treatment of rare diseases in Macedonia. They gave the following priorities: institutional frame for rare diseases, access to quality health services, access to social services, improvement of knowledge and access to information about rare diseases, and cooperation between all stakeholders, with involvement of organizations for rare diseases.

Dr Mirko Spiroski from the Zan Mitrev Clinic, Skopje, Republic of Macedonia, presented single center experience on RD genetics in the era of next generation sequencing. They performed bioinformatic analyses of the clinical exome (CES) $(n=26)$, whole exome (WES) $(n=8)$ and whole genome sequencing (WGS) $(n=3)$ data using Sophia DDM software, WuXi NextCODE, Geenox platform, and in-house developed scripts for Excel-based analyses. They concluded that genomic profiling with NGS technologies can provide molecular and physiological information of medical significance. A number of rare diseases associated mutations could be confirmed, either explaining the disease phenotype.

Dr Velibor Tasic from the Medical School Skopje, Macedonia gave a talk on pediatric nephrology in the era of NGS. The patients with Rare renal diseases (RRD) may undergo years, even decades, of numerous investigations including invasive procedures and yet do not have definitive and precise diagnosis and are not given opportunity to get appropriate treatment. The research interest of Macedonian clinicians and scientists is focused on genetics of congenital anomalies of the kidney and urinary tract (CAKUT), steroid resistant nephrotic syndrome, nephrolithiasis and nephrocalcinosis, cystic diseases and cilliopathies with collaboration with eminent laboratories in the United States and Europe. This collaboration resulted in detection of new genes and pathophysiological pathways in these laboratories with participation of patients from Macedonia (DSTYC, GANAB, TBX18, NRIP1, SLC26A1, SLIT2, SRGAP1, ITGA8, TRAP1, FRAS1, FREM2) which were published in high impact journals. Owing to WES we established a diagnosis of Dent 1 disease in two brothers with bilateral nephrocalcinosis, 28 years after initial presentation. WES established a diagnosis of the first case of urofacial syndrome in Macedonia, without any previous clinical suspicion. In ten of 50 children with nephrolithiasis/ nephrocalcinosis NGS established genetic diagnosis in $10(20 \%)$, eight of them had wrong clinical diagnosis. Exome trio analysis resulted in several incidental genetic findings related to serious diseases such as Bloom syndrome (BLC), Long QT interval (KCNH2), Retinitis pigmentosa (PDE6B, RPGR), RYR1 related myopathy, breast cancer (BRCA1), adenmatosis coli (APC), atypical hemolytic uremic syndrome (CFHR1).

Dr Zoran Gucev from the Medical Faculty in Skopje, Macedonia gave a talk on RDs that his team has diagnosed in the recent years. This is a group of metabolic, endocrine, renal, dysmorphic and genetic disorders that we have reported in the recent years. Gaucher, Morquio IVA and IVB, Hunter, Wilson, Lesch Nyhan, congenital erythropoetic porphyria, alkaptonuria have been diagnosed. In addition, Hunter, Morquio IVA have been treated for the first time with enzyme replacement therapy (ERT). A prenatal diagnosis was done in woman whose nephew had Hunter syndrome. Among the rare genetic endocrine disorders aldosteron synthase deficiency type II, precocious puberty, StAR deficiency, LHX4, idiopathic growth hormone deficiency type II, McCune Albright syndrome have been genetically confirmed and treated. WAGR, Rubinstein Taybi, CLOVE, Greenberg, craniofrontonasal (CFN) syndrome, Silver Russel syndrome were among those that were also diagnosed and reported. Among the renal diseases, Dent $1 / 2$, rare CAKUTs, Barter syndromes, aHUS have also been evaluated and reported. Total of 14 new genes have been discovered in Macedonian patients, in collaboration with several foreign laboratories. To mention just few: makorin ring finger 3 (MKRN3) was found in patients with central precocious puberty. PIK3CA in patients with segmental overgrowth, and TBX6 
in patients with SCD (and 7-10\% of patients with congenital scoliosis). New molecular mechanisms were described. A possible new disease, or a variant of Proteus syndrome, segmental overgrowth syndrome, has also been reported.

\section{Presentations from South Eastern Europe}

Dr Danko Milosevic from Zagreb, Croatia gave a talk on Croatian experience with the atypical hemolytic uremic syndrome (aHUS) in 5 children whose diagnosis was confirmed by kidney biopsy and extensive assessment of the alternative complement profile and genetic analysis. He concluded that the diagnosis of aHUS is still based on clinical judgment and the decision of Eculizumab treatment should be made before the arrival of genetic analysis. The success of the therapy should be measured by clinical/ laboratory improvement. All affected children had normal physical/mental status, but for one infant who showed mild mental retardation.

Dr Adrijan Sarajlija from the University of Belgrade, Serbia gave a talk on the spectrum of mitochondrial disorders in childhood. Joint prevalence of mitochondropathies could be estimated at 5-15:100,000 live births. It is of note that the mutations leading to mitochondrial diseases can occur in mitochondrial or in nuclear genome. These disorders have wide clinical heterogeneity. Accordingly, clinical manifestations can appear at any age, and practically all organs and systems can be affected by the pathologic process. Tissues highly dependent on energy supply are most severely affected in patients: brain, muscles (including heart), kidney, liver, intestinum, bone marrow, endocrine glands etc. Well-defined entities of mitochondrial disease are such as Leigh syndrome, MELAS, MERRF, Pearson syndrome, Alpers-Huttenlocher syndrome and others. In addition, those disorders can be a great challenge for the clinicians, both in diagnostic and therapeutic sense. NGS expanded the possibility of genetic diagnosis which can be determined in about $60 \%$ patients. Treatment of these disorders is based on the combination of vitamins, cofactors, alkalizing agents, symptomatic and supportive measures, and novel ones: resveratrol and sirtuin agonists.

Dr Ramush Bejiqi from Prishtina, Kosovo gave a talk on Klippel Feil syndrome associated with congenital heart disease. Klippel-Feil syndrome (KFS) is a rare congenital skeletal anomaly characterized primarily by defect in the formation or segmentation of the cervical vertebrae resulting in abnormal union or fusion of two or more bones of the spinal column (vertebrae) within the neck (cervical vertebrae). He presented four patients with KFS and congenital heart disease, diagnosed at different age, surgical treatment, and outcomes.

Dr Vjosa Mulliqi-Kotori gave a talk on hyperinsulinemic hypoglycemia of the neonate. Congenital hyperinsulinism is the most frequent cause of severe, persistent hypoglycemia in early infancy. Three patients, two girls and one boy had ABCC 8 gene alterations and were treated with diazoxide (a KATP channel agonist), subtotal pancreatectomy, Ocretoide and Nifedipine. Two patients responded well on medicamentous treatment.

Dr Mensuda Hasanhodžić from the University Clinical Center in Tuzla, Bosnia and Herzegovina gave talk on single centre experience with lipidoses. They presented 7 cases of different sphingolipidoses from different families, in patients who have non-consanguineous parents: First case is a girl with infantile type GM1 gangliosidosis, homozygous for a rare Y270D mutation in GLB1 gene (3p21.33), GM2 gangliosidosis, Tay Sachs disease, 2 cases of Niemann-Pick disease, and two sisters with Gaucher disease. All children have had healthy heterozygous parents.

\section{International (Germany, Austria, Czech Republic)}

Dr Ria Schönauer from the University Hospital Leipzig, Germany gave a talk on intrafamilial variability due to genetic modification in autosomal dominant polycystic kidney disease (ADPKD). This the most common hereditary renal disorder accounts for up to $10 \%$ of end-stage renal disease (ESRD) in western countries. ADPKD patients suffer from progressive kidney cyst formation, which results in severe organ enlargement, renal pain, hypertension and chronic kidney disease (CKD). Cyst development is caused by somatic mutations acquired during the course of life that lower the amount of the functional protein products polycystin 1 and 2 . Differences between unrelated patients can partly be explained by the affected polycystin gene, as pathogenic variants in PKD1 have a stronger impact on the progression compared to PKD2. Nevertheless, additional mutations within genes involved in the biosynthesis and signaling mechanisms of polycystins may lead to a clinically-relevant reduction of functional proteins.

Dr. Ruthild G. Weber, from the Hannover Medical School, Germany gave a presentation 
on the genetics of renal malformation and the new insights through next generation sequencing. Namely, before the advent of next generation sequencing (NGS), around 30 genes were known to be causative when mutated. NGS revealed new renal anomaly genes that encode transcription factors (PBX1, TBX18) or proteins involved in a number of different signaling pathways, e.g. interleukin-6-signaling (LIFR) and retinoic acid signaling (NRIP1 and GREB1L).

Dr Dieter Haffner from the Hannover Medical School, Germany gave a talk on the complications and management of X-linked hypophosphatemia (XLH). This is the most frequent inherited phosphate-wasting disorder with a prevalence of $1 / 20,000$. XLH is manifested by disproportionately short stature, rickets and osteomalacia starting early in life. Tooth abscesses are a quite frequent complications and are due to enemal hypoplasia and hypomineralized dentin resulting in microdefects and enlarged pulp chambers. Patients suffering from XLH have a loss-of-function mutation in the PHEX (phosphate-regulating gene with homologies to endopeptidase on the $\mathrm{X}$ chromosome) gene, leading to overexpression of the phosphaturic fibroblast growth factor 23 (FGF23) hormone in bone.

FGF23 has also direct actions on (growth) cartilage, ligaments and tendons thereby contributing to the overall high morbiditiy in these patients. Initiation of early treatment without overtreatment, i.e. within the first year of life, with active vitamin $\mathrm{D}$ [calcitriol or 1 alpha $(\mathrm{OH}) \mathrm{D} 3$ ] and oral doses of phosphate is of crucial importance in improving growth and hindering skeletal deformities in XLH patients. A new promise has been demonstrated with treatment with FGF23 antibodies.

Dr Julia Hoefele from the Technical University of Munich, Germany presented data on the impact of genetic modifiers in female patients with Alport syndrome (AS). AS is a genetic nephropathy characterized by hematuria, proteinuria, progressive renal failure leading to chronic kidney disease, hearing loss, and typical ocular changes. AS is caused by mutations in the genes encoding collagen IV leading to a defective glomerular basement membrane. The focus of their study is the identification of factors influencing and explaining the phenotypic variability in female patients with X-linked AS. As possible causes for phenotypic variability is the type of mutation, genetic modifiers or degree of mosaicism following lyonization of the $\mathrm{X}$ chromosome are discussed.
Dr Johannes A. Mayr, Paracelsus Medical University Salzburg, Austria, gave a talk on NGS revealing new treatable diseases. Genetic diseases are often untreatable. However, at least in $10 \%$ of these disorders therapeutic interventions have been suggested, while in several a complete cure is possible (e.g.phenylketonuria). An expanded newborn-screening has been established in the early 2000 s in many countries, increasing the number of screened diseases up to 30 . New treatment options are available. Some are simple and inexpensive while others are extremely expensive, creating a burden for the health system and difficult medical versus economic decisions. Next generation sequencing has the potential to cover the screening for all treatable genetic diseases.

Dr O. Bartsch from the Johannes Gutenberg University, Mainz, Germany gave an update on preimplantation genetic diagnosis (PGD). As many parents with a child with a severe hereditary disease want another healthy child, they fear for the high risk (frequently $25 \%$ ) of having another diseased fetus. PGD poses new ethical problems, but following intensive discussions PGD became possible under German law in 2015. German PGD ethics committees make free decisions whether to allow or not the PGD in an authorised medical center. PGD always requires in-vitro fertilization (IVF). At day 5 or 6 , some (10+) cells are removed from the embryo and used for genetic diagnosis. The genetic testing requires specially trained staff and special laboratory conditions. A single PGD center located at Mainz University covers a population of 10.2 million, making Mainz one of the largest German PGD centers. PGD for cytogenetic abnormalities using commercial microarrays, as well as is performed by all PGD for Mendelian (monogenic) disorders. He concluded that despite the ethical issues, technical demands and costs, PGD has become an essential technique in his center after only two years.

Dr Martin Magner from the First Faculty of Medicine, Charles University, Czech Republic gave a talk on Mucopolysaccharidoses (MPS). These are lysosomal storage disorders caused by low activity of some of eleven lysosomal hydrolytic enzymes degrading the glycosaminoglycans (GAGs, originally mucopolysaccharides). Clinical signs evolve gradually and depend on the MPS type and its severity. Variably expressed coarse facial features with frontal bossing, prominent eyebrows, broad nasal root, anteverted nostrils, full lips and wide-spaced teeth may develop. Hep- 
atomegaly and splenomegaly are present, mainly in type MPS I, II and VI. Bone involvement with short stature, backbone deformities, and characteristic Xray changes outlined as dysostosis multiplex are constant features. The dominant skeletal involvement is characteristic for MPS IV, in which the severe visceral organ and cognitive involvement are absent. The heart valves are also affected by GAGs storage leading to valve disorders and secondary cardiomyopathy. The lung involvement is characterized by combined obstructive and restrictive disorders. The developmental delay is typical for severe forms of MPS I, II and III, respectively. On contrary, it is not present in MPS IV and VI. The psychiatric symptomatology with behavioral problems (hyperactivity, aggressivity) is typical for MPS III. The enzyme replacement therapy (ERT) has brought a significant change to the prognosis of patients with MPS. It has no effect on CNS impairment. The early diagnosis and therapy introduction is essential for its maximum benefit.

Electronic poster sessions were the following:

1. Ambarkova V et al. Patient With Cleft Lip And Palate- A Case Report

2. Jovanovski-Srceva $M$ et al. Anesthesia For Patient With Louis Bar Syndrome

3. Stamatova A et al. Ectodermal Dysplasia In Two Brothers

4. Bogevska I et al.Tissue Specific Crebbp Mosaicism In A Patient With Rubinstein-Taybi Syndrome

5. Janchevska A et al. A 9.5 Year Old Boy With Familial Male Central Precoccious Puberty

6. Simic I et al. Anesthetic Chalenges In A Child With Arthrogryposis Multiplex Congenita Presented For Limb Surgery
7. Fustik S et al. The Importance Of An International Registry For Patients With Cystic Fibrosis

8. Alili Ademi L et al. Myasthenia Gravis In A Girl With Hashimoto's Thyroiditis

9. Markovska-Simoska S et al. Girl With 22q11.2 Deletion Syndrome Manifesting Psychotic Symptoms: Case Report

10. Momirovska A et al. Wilson Disease, Mutation c.3207C.a (p.his1069gln) In Atp7b Gene, In Patients In Republic Of Macedonia

11. Mehandziska S et al. Rare Is Not A Diagnostic Scare: Exome Sequencing For Diagnostics Of Rare Diseases.

12. Stajkovska A et al. In The Heart Of The Matter: Exome Sequencing For Diagnostics Of Arrhythmic Syndromes And Other Cardiovascular Conditions

13. Stamatova A et al: Familial Form Of Congenital Unilateral Micromastia

\section{CONCLUSIONS}

A wide spectrum of rare diseases were presented at the Conference, mainly pediatric, genetic, nephrological and metabolic. The lecturers emphasized the role of next generation sequencing technologies for early and accurate diagnostics of rare disease, understanding new pathophysiological pathways and treatment modalities in concert with the concept for personalized genetic medicine. The lecturers presented many examples on how next generation sequencing enabled establishing correct diagnosis in patients who had been investigated for many years (diagnostic Odyssey) and undergone many invasive and unpleasant procedures (treatment Golgotha). 


\title{
Резиме
}

\section{ШЕСТИ СОСТАНОК ЗА РЕТКИ БОЛЕСТИ НА ЈУГОИСТОЧНА ЕВРОПА, СКОПЈЕ, МАКЕДОНИЈА (11 НОЕМВРИ 2017 ГОДИНА)}

\author{
Зоран Гучев ${ }^{1}$, Велибор Тасиќ́ ${ }^{1}$, Момир Поленаковиќ ${ }^{2}$ \\ ${ }^{1}$ Универзитетска клиника за детски болести, Медицински факултет, Скопје, Република Македонија \\ ${ }^{2}$ Македонска академија на науките и уметностите, Скопје, Република Македонија
}

Шестата конференција за ретки болести во Југоисточна Европа се одржа на 11 ноември во јубилејната година - педесет години од основањето на Македонската академија на науките и уметностите. За целиот овој период Академијата силно ги поддржа научните активности во земјата, но исто така, и во регионот и на меѓународно ниво. Оваа година научници и лекари од Македонија, Србија, Хрватска, Босна и Херцеговина, Косово, Австрија и Германија ги презентираа своите достигнувања во современата дијагностика и третманот на пациенти со ретки болести. Беа презентирани широк спектар на ретки болести - главно, педијатриски, генетски, нефролошки и метаболички. Предавачите ја истакнаа улогата на технологиите за секвенционирање од следната генерација за рана и точна дијагностика на ретките болести, разбирањето на нови патофизиолошки патишта и модалитети на третман во согласност со концептот за персонализирана генетска медицина. Предавачите презентираа многу примери како секвенционирањето од следната генерација овозможува воспоставување точна дијагноза кај пациенти што биле испитувани многу години (дијагностичка Одисеја) и поминале низ многу инвазивни и непријатни процедури (третман Голгота).

Клучни зборови: ретки болести, конференција, Југоисточна Европа, генетика, секвенционирање од следната генерација 